\title{
P260: Step assessment of nosocomial infections control in Sengal (Pronalin)
}

\author{
BK Oumar Thiam \\ From 2nd International Conference on Prevention and Infection Control (ICPIC 2013) \\ Geneva, Switzerland. 25-28 June 2013
}

\section{Introduction}

As a member state of WHO, Senegal, has committed to take up the global challenge of nosocomial infections control by setting up a national program since 2004. A road map including administrative and organizational measures as well as technical activities had been shared with all health structures.

\section{Objectives}

The objective of this work is to evaluate the implementation of the program.

\section{Methods}

A supervision guide had been elaborated based on the activities outlined in the roadmap. We conducted a formal evaluation of these activities.

\section{Results}

95\% of the health structures have set up an institutional framework as well as prioritized workgroups; hand washing activities and biomedical waste management has been carried out partially. $95 \%$ of health structures did not carry out any activity on care infection surveillance; only $38 \%$ of the health institutions have set up a local section for patient security.

\section{Conclusion}

Setting up an institutional framework as well as prioritized workgroups was a success. However, it should be mentioned that implementation of the roadmap activities could have been better.

\section{Competing interests}

None declared.

\section{Published: 20 June 2013}

Coordinator of PRONALIN, Dakar, Senegal
doi:10.1186/2047-2994-2-S1-P260

Cite this article as: Thiam: P260: Step assessment of nosocomial infections control in Sengal (Pronalin). Antimicrobial Resistance and Infection Control 2013 2(Suppl 1):P260.
Submit your next manuscript to BioMed Central and take full advantage of:

- Convenient online submission

- Thorough peer review

- No space constraints or color figure charges

- Immediate publication on acceptance

- Inclusion in PubMed, CAS, Scopus and Google Scholar

- Research which is freely available for redistribution 